\title{
Spray chilling on carcass weight loss, and physicochemical and microbiological quality of beef cuts during storage
}

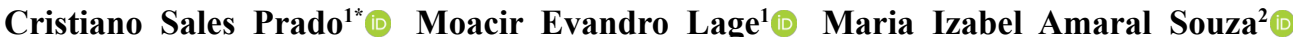 \\ Francine Oliveira Souza Duarte ${ }^{2}$ Clarice Gebara ${ }^{1}$ (i) Edmar Soares Nicolau $^{1}$ \\ Iolanda Aparecida Nunes ${ }^{1}$ Antônio Nonato de Oliveira ${ }^{1}$ Cintia Silva Minafra-Rezende ${ }^{1}$
}

${ }^{1}$ Centro de Pesquisa em Alimentos, Escola de Veterinária e Zootecnia, Universidade Federal de Goiás (UFG), 74690-900, Goiânia, GO, Brasil. E-mail: cristiano_prado@ufg.br. "Corresponding author.

${ }^{2}$ Programa de Pós-graduação em Ciência Animal, Universidade Federal de Goiás (UFG), Goiânia, GO, Brasil.

\begin{abstract}
Different chilling treatments are used before meat storage. The effect of spray chilling (SC) on meat quality appears to vary. Here, we investigated the effects of SC on beef carcass weight loss and meat quality during subsequent storage. The 2-h SC program tested involved 180-s initial spraying, followed by 60-s spray cycles at 540-s intervals. Deboned chuck tender (IMPS $116 B$ ) beef cuts were vacuumpackaged and stored for up to $60 \mathrm{~d}$. Purge and cooking losses, Warner-Bratzler shear force, meat colour [CIE $L^{*}$, a*, $\left.b^{*}\right]$, and microbiological quality were evaluated. SC reduced carcass weight loss $(P<0.001)$ compared with conventional chilling. However, storage time affected the purge and cooking losses, and Warner-Bratzler shear force. CIE $a^{*}$ and $b^{*}$ values increased $(P<0.05)$ after 30-d aging in both chilling treatments. Pronounced psychrotrophic growth was observed during storage after both treatments. In conclusion, SC can be used to reduce the economic losses associated with meat chilling, without affecting meat quality attributes.
\end{abstract}

Key words: beef carcass, weight loss, chilling, microbiology, purge, tenderness, colour.

Efeitos da aspersão de carcaças na perda de peso e na qualidade físico-química e microbiológica de cortes cárneos bovinos durante estocagem

RESUMO: Diferentes tratamentos de resfriamento são utilizados antes da estocagem das carnes. O efeito da aspersão de carcaças (SC) na qualidade da carne parece variar. Neste estudo, investigou-se os efeitos da aspersão de carcaças bovinas na perda de peso e na qualidade da carne durante subsequente estocagem. O programa de aspersão testado foi de um tempo total de $2 \mathrm{~h}$, com uma aspersão inicial de $180 \mathrm{~s}$, seguida por ciclos de aspersão de $60 \mathrm{~s}$ em intervalos de $540 \mathrm{~s}$. Os cortes comerciais desossados "Peixinho" (IMPS $116 \mathrm{~B})$ foram embalados a vácuo e estocados por até 60 dias. Foram avaliadas as perdas por exsudação e cozimento, força de cisalhamento por Warner-Bratzler, cor da carne $\left(C I E L^{*}, a^{*}, b^{*}\right)$ e qualidade microbiológica. $S C$ reduziu a perda de peso da carcaça $(P<0,001)$ em comparação com o resfriamento convencional. No entanto, o tempo de estocagem influenciou a perda por exsudação, por cozimento e força de cisalhamento. Os valores de CIE $a^{*}$ e $b^{*}$ aumentaram $(P<0,05)$ após 30 dias de maturação em ambos os tratamentos de resfriamento. O crescimento pronunciado de psicrotróficos foi observado durante a estocagem em ambos os tratamentos. Em conclusão, o SC pode ser usado para reduzir as perdas econômicas associadas ao resfriamento da carne, sem afetar os atributos de qualidade da carne.

Palavras-chave: carcaças bovinas, resfriamento, microbiologia, exsudação, maciez, cor

\section{INTRODUCTION}

The degree of acceptance of meat by the consumer is directly affected by several factors related to livestock production and industrial processing. Many factors that affect meat quality have been studied, e.g. pre-slaughter conditions, $\mathrm{pH}$ decline, chilling conditions, electrical stimulation, and aging, among many others (MOMBENI et al., 2013; MUCHENJE et al., 2009).

Water loss by dripping or exudation can influence the juiciness of cooked meat and the appearance of vacuum-packaged meat cuts in retail. Therefore, it may also influence consumer acceptance during purchase. Weight loss during conventional chilling can be caused by natural exudation and surface evaporation, in some cases reaching almost $2 \%$, with a considerable economic impact on the industry. According to JONES \& ROBERTSON (1988), spray chilling (SC) can be used to avoid or reduce the weight loss of carcass during chilling, and has been employed in the US and Canada since 1987.

The SC spray system comprises a simple device made of PVC pipes with sprinkler nozzles, 
organized along the sides of the rails, inside a carcass cooler. Cold water is intermittently sprayed in an automated pre-programmed cycle. The total time of the program, spraying cycles, and intervals between cycles can influence the degree of weight loss during storage. Generally, SC efficiently reduces weight loss by evaporation (ALLEN et al., 1987; PRADO \& DE FELÍCIO, 2010; MESQUITA et al., 2003). However, depending on how the cycles are programmed, a carcass may gain weight instead of losing, by absorbing water or forming small water pockets, as observed by JANZ \& AALHUS (2006) who evaluated bison carcass quality after SC. Further, to evaluate the efficiency and safety of any chilling system, meat quality should be monitored with extended storage time, considering the possibility of some physicochemical and/or microbiological changes that might be detrimental to the quality of the final product.

The current study evaluated the effects of SC on carcass weight loss, quality, and surface microbiology during chilling. Specifically, we investigated purge and cooking losses, shear force, colour, and microbiological quality of chuck tender (IMPS 116B) beef cuts (USDA, 2014) after SC and conventional air chilling (CC), at different storage times.

\section{MATERIALS AND METHODS}

\section{Animals, slaughter, and chilling treatments}

Eighteen non-castrated bulls (Nelore cattle), aged 24 months (on average), finished in a feedlot at Goiás State, Brazil, were slaughtered according to the Brazilian Industrial and Sanitary Inspection Regulation for Animal Origin Products (BRASIL, 2017). No electrical stimulation was used after bleeding. Carcasses were weighed before chilling (the initial weight) and randomly assigned to two chilling treatments $(n=9$ carcasses for each treatment), CC or SC. The setting point temperature of the cooler was adjusted to $2{ }^{\circ} \mathrm{C}\left( \pm 1{ }^{\circ} \mathrm{C}\right)$ during $24 \mathrm{~h}$ for both treatments. The total spraying time for the SC treatment was $2 \mathrm{~h}$ (water temperature at $4{ }^{\circ} \mathrm{C}$ ), with an initial 180 -s spraying followed by subsequent cycles of 60-s spraying at 540-s intervals. After chilling, the carcasses were weighed again (the final weight) and weight loss was calculated based on the weight difference. The spraying cycle began immediately after the cooler door was closed. The post mortem $\mathrm{pH}$ decline was measured using a $\mathrm{pH}$ meter (HANNA instruments, model HI99163 - Nusfalau, Romania - USA) with probes inserted at 5-cm depth into the muscle longissimus dorsi, between ribs 9 and
10. At the same location but on the other side of the carcass, the intramuscular temperature reduction was registered using a data logger (model 176, Testo).

\section{Sample collection and storage}

Approximately $1000 \mathrm{~mL}$ of SC water was collected before spraying directly from the sprinkler nozzles to evaluate its quality. For microbiological evaluation of carcass surfaces, before and after chilling, $100-\mathrm{cm}^{2}$ samples from the carcass surface were collected using a $3 \mathrm{M}^{\mathrm{TM}}$ Hydrated-Sponges ${ }^{\circledR}$ at three different locations (the rump, loin, and brisket), $300 \mathrm{~cm}^{2}$ total per carcass. After chilling, the supraspinatus muscle, i.e. the chuck tender (IMPS 116B), from all carcasses, was deboned, individually vacuum-packed, and the beef cuts randomly assigned to three storage groups (7-, 30-, or 60-d storage). The beef cuts was stored between 0 and $2{ }^{\circ} \mathrm{C}(\mathrm{n}=6$ beef cuts for each chilling treatment and storage time).

\section{Microbiological analyses}

Total aerobic mesophilic counts (ISO 6222:1999, 1999), and total and thermotolerant coliforms Most Probably Number (APHA, 2012) were determined in the water samples.

For meat analysis, at the end of each storage period, the packed samples were aseptically opened, and $25 \mathrm{~g}$ were carved out and placed in a sterile stomacher bag with $225 \mathrm{~mL}$ of buffered peptone water $(1 \%)$, and homogenized for $60 \mathrm{~s}$. The microbiological analyses of carcass surface and beef cuts involved the detection of Salmonella spp. (ISO 6579:2002; 2004/COR1:2004, 2004), and enumeration of Enterobacteriaceae (ISO 215282:2004, 2004), psychrotrophic microorganisms (AOAC 990.12 - 1994 (2002)), and Escherichia coli (AOAC 998.08-2002, 2002). Bacterial counts are reported as the base-10 logarithm of colony-forming units (cfu) per $\mathrm{cm}^{2}\left(\log _{10} \mathrm{cfu} / \mathrm{cm}^{2}\right)$.

\section{Physicochemical parameter and Warner-Bratzler shear force analyses}

At the end of each storage period, the packed samples were weighed, opened to remove the exudate, and then the meat and vacuum bag were wiped with a paper towel and weighed together. Purge loss was calculated based on the weight difference. Surface colour, WB shear force, and cooking losses were evaluated in 2.5-cm-thick chuck tender steak. Instrumental meat colour CIE L* (lightness), $\mathrm{a}^{*}$ (redness), and $b^{*}$ (yellowness) (CIE, 1976) were analysed using a Minolta $\mathrm{BC}-10$ apparatus $\left(8^{\circ}\right.$ :di illumination angle/diffuse viewing, 8 -mm measuring 
area, with a gas-filled tungsten lamp as a light source, previously calibrated against a white plate supplied by the manufacturer). The steaks were rested for 30 minutes under room conditions to allow for surface blooming before the measurements. Measurements were done for three areas of each steak (left, centre, and right). $\mathrm{C}^{*}$ (Chroma) and $\mathrm{h}^{\circ}$ (hue angle) values were calculated from $\mathrm{a}^{*}$ and $\mathrm{b}^{*}$ values with $\mathrm{C}^{*}$ as $\left(\mathrm{a}^{* 2}+\right.$ $\left.b^{* 2}\right)^{1 / 2}$ and $h^{\circ}$ as arctangent $\left(b^{*} / a^{*}\right)$, according to AMSA (2012). The final data are expressed as the arithmetic mean of the three measurements.

Before cooking, the steaks were individually weighed on a metal rack over an aluminium tray to calculate the cooking loss. Steaks were cooked using an electric oven with a top and bottom electrical resistance. Temperature was adjusted to $170{ }^{\circ} \mathrm{C}$ (pre-heated) and the steak internal temperature was monitored by using individual probes, until the meat reached $71{ }^{\circ} \mathrm{C}$. Cooking loss was determined based on the weight difference before and after cooking. Cooked steaks were next packed into individual plastic bags and chilled at $7{ }^{\circ} \mathrm{C}$ overnight. Six $1.27-\mathrm{cm}$ cores per steak were used for shear force measurements using the Warner-Bratzler Meat Shear (GR Manufacturing Co. Manhattan, model 300), according to WHEELER et al. (1998).

\section{Statistical analysis}

Results were evaluated by using $R$ statistical program, version 3.5.0. Mean values were compared by Tukey's and Duncan's tests $(\mathrm{P}<0.05)$. For the microbiological analyses, a nonparametric test (Kruskal-Wallis) was used for multiple comparisons.

\section{RESULTS AND DISCUSSION}

\section{Effect of SC on meat weight loss}

The SC treatment did not significantly affect the post mortem $\mathrm{pH}$ and intramuscular temperature decline $(\mathrm{P}>0.05)$. However, a significant difference $(\mathrm{P}<0.001)$ was observed in the effect of $\mathrm{SC}$ and $\mathrm{CC}$ on the carcass weight loss (Table 1). The major purpose of using the SC system, i.e. reducing the carcass weight loss, was therefore accomplished. The mean weight loss in the SC group was $1.09 \%$, while it was $1.73 \%$ in the CC group, despite the short spraying time used. Similar observations were reported by others, who noted a reduced weight loss of carcasses from different species (beef, lamb, pork, bison, and venison) after SC (PRADO \& DE FELÍCIO, 2010; BROWN et al., 1993; GIGIEL et al., 1989; JANZ \& AALHUS, 2006; WIKLUND et al., 2010). The observed percentage difference for the SC and CC treatments is very important from an industrial perspective because of a potential economic impact. When considering the weight loss observed in sprayed carcasses, the SC treatment saved almost $2.0 \mathrm{~kg}$ per animal.

Effect of SC on purge loss, cooking loss, and WB shear force

The SC treatment did not affect purge loss, cooking loss, and WB shear force $(\mathrm{P}>0.05$, Table 2$)$, when compared with CC treatment. Similar, GREER et al. (1990) compared SC and CC, and reported no difference in purge loss from tenderloins after up to $70 \mathrm{~d}$ of vacuum storage. STRYDOM \& BUYS (1995) and GREER \& JONES (1997) reported similar observations. However, others reported different observations (ALLEN et al.; 1987; PRADO \& DE FELÍCIO, 2010). PRADO \& DE FELÍCIO (2010) compared the muscle L. lumborum beef steaks from carcasses chilled with or without spraying, stored for up to $60 \mathrm{~d}$, and observed higher loss in sprayed carcasses $(1.79 \%)$ than in non-sprayed carcasses $(1.34 \%)$. This suggested that the weight saved during $\mathrm{SC}$ could be lost during storage. A lack of difference in purge loss between treatments could be explain by the short time of total spraying and also by the location of the supraspinatus muscle, i.e. on the forequarter, which was positioned relatively far from the source of water during spraying. Similar, this may explain the lack of difference between treatments on cooking loss, as also reported by STRYDOM \& BUYS (1995) and PRADO \& DE FELÍCIO (2010), who observed no difference in cooking losses of beef steaks from carcasses chilled using the spray system compared with conventional system.

Results of the WB shear force analysis were in agreement with those of others who reported no difference in shear force of carcasses with or without spray-chilling (GREER \& JONES, 1997; PRADO \& DE FELÍCIO, 2010). There were no differences in the carcass chilling rates in the SC and $\mathrm{CC}$ chilling rooms. This may explain the observations presented herein as the chilling rate is a factor that influences the meat shear force (PRADO \& DE FELÍCIO, 2010; FERNÁNDEZ \& VIEIRA, 2012; JACOB et al., 2012).

The storage time affected purge loss, cooking loss, and WB shear force (Table 2). This was anticipated since the increase of purge and cooking losses with storage time has been reported before. PRADO \& DE FELÍCIO (2010) observed increase in purge losses with increasing storage time, comparing 7-, 14-, 30-, and 60-d storage of beef strip loin steaks 
Table 1 - The initial and final weight, and weight loss during carcass chilling ( $\mathrm{n}=9$ for each chilling treatment).

\begin{tabular}{|c|c|c|c|c|}
\hline Treatment & ------Initial weight $(\mathrm{kg})$------ & ----Final weight $(\mathrm{kg})$---- & ----Weight loss (kg)---- & ----Weight loss (\%)---- \\
\hline $\mathrm{SC}$ & $289.04 \pm 5.56^{\mathrm{a}}$ & $285.91 \pm 5.58^{\mathrm{a}}$ & $3.13 \pm 0.24^{\mathrm{a}}$ & $1.09 \pm 0.09^{\mathrm{a}}$ \\
\hline $\mathrm{CC}$ & $295.33 \pm 5.56^{\mathrm{a}}$ & $290.24 \pm 5.58^{\mathrm{a}}$ & $5.09 \pm 0.24^{\mathrm{b}}$ & $1.73 \pm 0.09^{b}$ \\
\hline
\end{tabular}

SC, spray chilling; CC, conventional air chilling. Data are shown as the mean \pm standard error of the mean. Means in the same column denoted by different letters are significantly different. Duncan's tests $(\mathrm{P}<0.05)$.

chilled with or without SC. Further, lower WB shear force of steaks stored for 30 and $60 \mathrm{~d}$ than that stored for 7 and $14 \mathrm{~d}$ was also anticipated, since the aging process is a useful technique for improving beef tenderness by allowing for longer proteolysis of meat protein (TROY \& KERRY, 2010; FRANCO et al., 2009).

\section{Effect of SC on meat colour}

Instrumental meat colour data are presented in table 3 . No significant differences in CIE L* (lightness), a* (redness), $b^{*}$ (yellowness), $C^{*}$ (chroma) and $\mathrm{h}^{\circ}$ (hue angle) values of chuck tender steaks were apparent between the chilling treatments $(\mathrm{P}>0.05)$. This was in agreement with findings of others (JONES \& ROBERTSON, 1988; GREER et al., 1990; BROWN et al., 1993; GREER \& JONES, 1997). Meat colour may be associated with muscle temperature during the rigor establishment (JACOB \& THOMSON, 2012; ROSENVOLD \& WIKLUND, 2011). No differences between the carcass chilling rate were apparent between the chilling treatments and, hence, during the rigor establishment, which might explain the above findings.

Visual appearance of meat, such as colour, is very important to the consumer and may influence the purchase decision at the point of sale, since it is used as an indicator of freshness. Myoglobin concentration and its physicochemical state influence the overall meat colour. The major reason for undertaking an objective instrumental meat colour evaluation is to aid visual evaluation and to provide impartial evidence of any effect of treatment (AMERICAN MEAT SCIENCE ASSOCIATION, 2012). The data presented herein; therefore, indicated that $\mathrm{SC}$ does not influence the colour of lean meat. However, the storage time affected the $\mathrm{a}^{*}$ (redness), $\mathrm{b}^{*}$ (yellowness), $\mathrm{C}^{*}$ (chroma) and $\mathrm{h}^{\circ}$ (hue angle) values $(\mathrm{P}<0.05)$, which were increased after 30 -d storage after both chilling treatments (Table 3). The influence of aging time on beef colour has been reported (LINDAHL, 2011; LEE et al., 2008). MANCINI \& RAMANATHAN (2014) reported a significant effect of storage time and temperature on the initial colour intensity $(\mathrm{P}<$ 0.05); with increasing aging time, the initial colour also increased. Similar, when the a* value was used to evaluate the initial colour intensity, the redness increased with an increasing aging time $(\mathrm{P}<0.05)$. That was probably because the mitochondrial activity decreases with prolonged storage time (MANCINI \& RAMANATHAN, 2014), which improved the initial

Table 2 - Purge loss, cooking loss, and Warner-Bratzler shear force (WB) of chuck tender steaks depending on the chilling treatment and storage time ( $\mathrm{n}=6$ for each chilling treatment/storage time).

\begin{tabular}{|c|c|c|c|c|c|c|c|c|c|}
\hline & Purge loss $(\%)$ & Cook loss $(\%)$ & $\mathrm{WB}(\mathrm{N})$ & Purge loss $(\%)$ & Cook loss $(\%)$ & $\mathrm{WB}(\mathrm{N})$ & Purge loss $(\%)$ & Cook loss $(\%)$ & $\mathrm{WB}(\mathrm{N})$ \\
\hline & \multicolumn{3}{|c|}{ 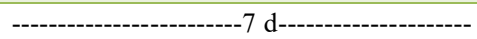 } & \multicolumn{3}{|c|}{-----------------------30 d---------------------- } & \multicolumn{3}{|c|}{---------------------60 d------------------' } \\
\hline $\mathrm{SC}$ & $0.36^{\mathrm{A}}$ & $9.91^{\mathrm{A}}$ & $36.53^{\mathrm{A}}$ & $1.13^{\mathrm{A}}$ & $9.66^{\mathrm{A}}$ & $29.47^{\mathrm{B}}$ & $3.63^{\mathrm{B}}$ & $12.57^{\mathrm{B}}$ & $30.51^{\mathrm{B}}$ \\
\hline $\mathrm{CC}$ & $0.49^{\mathrm{A}}$ & $9.63^{\mathrm{A}}$ & $35.52^{\mathrm{A}}$ & $1.61^{\mathrm{B}}$ & $8.47^{\mathrm{A}}$ & $30.40^{\mathrm{B}}$ & $4.72^{\mathrm{C}}$ & $10.71^{\mathrm{A}}$ & $33.37^{\mathrm{AB}}$ \\
\hline $\mathrm{p}$-value & 0.129 & 0.832 & 0.749 & 0.15 & 0.457 & 0.701 & 0.113 & 0.078 & 0.110 \\
\hline
\end{tabular}

SC, spray chilling; CC, conventional air chilling. Mean values for SC and CC data are shown. Means for the same parameter in the same column denoted by different lower case letters are significantly different. Means for the same parameter in the same line denoted by different upper case letters are significantly different. Duncan's tests $(\mathrm{P}<0.05)$. 
Table 3 - The instrumental meat colour of chuck tender steaks depending on the chilling treatment and storage time ( $\mathrm{n}=6$ for each chilling treatment/storage time).

\begin{tabular}{|c|c|c|c|c|}
\hline \multirow[t]{2}{*}{ Storage time } & \multirow[t]{2}{*}{-----Colour parameter----- } & \multicolumn{2}{|c|}{ 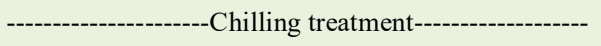 } & \multirow[t]{2}{*}{----------p-value-------- } \\
\hline & & 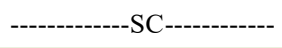 & ------------CC------------- & \\
\hline \multirow{5}{*}{$7 d$} & $\mathrm{~L}$ & $40.80^{\mathrm{a}}$ & $40.65^{\mathrm{a}}$ & 0.882 \\
\hline & $a^{*}$ & $14.10^{\mathrm{a}}$ & $15.61^{\mathrm{a}}$ & 0.158 \\
\hline & $b^{*}$ & $6.17^{\mathrm{a}}$ & $6.75^{\mathrm{a}}$ & 0.303 \\
\hline & $\mathrm{C}^{*}$ & $15.39^{\mathrm{a}}$ & $17.02^{\mathrm{a}}$ & 0.167 \\
\hline & $\mathrm{h}^{\circ}$ & $23.55^{\mathrm{a}}$ & $23.37^{\mathrm{a}}$ & 0.855 \\
\hline \multirow{5}{*}{$30 \mathrm{~d}$} & $\mathrm{~L}$ & $41.58^{\mathrm{a}}$ & $41.56^{\mathrm{a}}$ & 0.975 \\
\hline & $a^{*}$ & $17.55^{\mathrm{b}}$ & $18.21^{\mathrm{b}}$ & 0.550 \\
\hline & $b^{*}$ & $7.81^{\mathrm{b}}$ & $8.25^{\mathrm{b}}$ & 0.500 \\
\hline & $\mathrm{C}^{*}$ & $19.21^{b}$ & $20.00^{\mathrm{b}}$ & 0.529 \\
\hline & $\mathrm{h}^{\circ}$ & $24.03^{\mathrm{ab}}$ & $24.27^{\mathrm{ab}}$ & 0.767 \\
\hline \multirow{5}{*}{$60 \mathrm{~d}$} & $\mathrm{~L}$ & $42.08^{\mathrm{a}}$ & $41.33^{\mathrm{a}}$ & 0.385 \\
\hline & $a^{*}$ & $17.85^{\mathrm{b}}$ & $18.73^{b}$ & 0.351 \\
\hline & $b^{*}$ & $8.41^{\mathrm{b}}$ & $8.78^{\mathrm{b}}$ & 0.538 \\
\hline & $\mathrm{C}^{*}$ & $19.74^{\mathrm{b}}$ & $20.69^{b}$ & 0.375 \\
\hline & $\mathrm{h}^{\circ}$ & $25.20^{\mathrm{b}}$ & $25.10^{\mathrm{b}}$ & 0.905 \\
\hline
\end{tabular}

SC, spray chilling; CC, conventional air chilling; $L^{*}$, lightness; $a^{*}$, redness; $b^{*}$, yellowness; $C^{*}$, Chroma; $h^{\circ}$, hue angle. Mean values for SC and CC data are shown. Means for the same colour parameter in the same column denoted by different lower case letters are significantly different. Means for the same colour parameter in the same line denoted by different upper case letters are significantly different. Duncan's tests $(\mathrm{P}<0.05)$.

colour intensity of steaks by minimizing the competition for oxygen between myoglobin and mitochondria (MAC DOUGALL, 1982). Therefore, oxygen is allowed to penetrate deeper, enhancing the extent of the initial oxymyoglobin formation beneath the surface.

\section{Effect of SC on microbiological quality of meat}

The analysis revealed good microbiological water quality, with $1.34 \log _{10} \mathrm{cfu} /$ $\mathrm{ml}$ of total aerobic mesophilic counts, and less than $1.10 \mathrm{MPN} / 100 \mathrm{~mL}$ of total and thermotolerant coliforms. This indicated that no new microbial load was deposited on the carcass surface during the SC treatment. Microbiological evaluation of the carcasses (Table 4) revealed low counts of Enterobacteriaceae and E. coli, and the absence of Salmonella spp. after both chilling treatments. The psychrotrophic counts were within acceptable limits.

Table 4 - Microbiological evaluation of carcass surfaces after SC and CC treatments, before and after chilling ( $\mathrm{n}=6$ for each chilling treatment).

\begin{tabular}{|c|c|c|c|c|c|}
\hline \multicolumn{2}{|c|}{ Treatment } & \multirow{2}{*}{$\begin{array}{l}\text { Enterobacteriaceae } \\
\qquad \begin{array}{c}\left(\log _{10} \mathrm{cfu} / \mathrm{cm}^{2}\right) \\
<1.0\end{array}\end{array}$} & \multirow{2}{*}{$\begin{array}{c}\text { E. coli } \\
\left(\log _{10} \mathrm{cfu} / \mathrm{cm}^{2}\right) \\
<1.0\end{array}$} & \multirow{2}{*}{$\begin{array}{l}\text { Psychrotrophs } \\
\left(\log _{10} \mathrm{cfu} / \mathrm{cm}^{2}\right) \\
2.14\end{array}$} & \multirow{2}{*}{$\begin{array}{l}\text { Salmonella spp } \\
\left(\mathrm{cfu} / 300 \mathrm{~cm}^{2}\right)\end{array}$} \\
\hline $\mathrm{S} C$ & Before chilling & & & & \\
\hline $\mathrm{SC}$ & After chilling & $<1.0$ & $<1.0$ & 2.46 & 0 \\
\hline \multirow[b]{2}{*}{$\mathrm{CC}$} & Before chilling & $<1.0$ & $<1.0$ & 1.07 & 0 \\
\hline & After chilling & $<1.0$ & $<1.0$ & 2.10 & 0 \\
\hline
\end{tabular}

SC, spray chilling; CC, conventional air chilling. Data are shown as the means. Nonparametric test - Kruskal-Wallis $(\mathrm{P}<0.05)$. 
These findings indicated a good microbiological quality of the meat-processing environment, evidencing suitable hygienic and sanitary procedures during slaughter and chilling, which could result in a relatively long shelf life.

Further, SC did not affect the microbiological quality of beef cuts after storage, even though an increase in bacterial population was observed during storage (Table 5). These findings were similar to those reported by others (STRYDOM \& BUYS, 1995; GREER \& JONES, 1997). Enterobacteriaceae counts reached $3.24 \log _{10} \mathrm{cfu} / \mathrm{cm}^{2}$ for SC samples and $1.74 \log _{10} \mathrm{cfu} / \mathrm{cm}^{2}$ for CC samples after $60 \mathrm{~d}$ storage time, but no significant differences were observed between treatments.

From another perspective, the ecology of the bacterial deterioration of meat at low temperature is associated with some extrinsic factors (such as the aerobic and/or anaerobic gas atmosphere, environmental humidity, and previous exposure to other bacteria) and intrinsic factors ( $\mathrm{pH}$ and water activity). These factors shape the diversified ecosystem represented by Enterobacteriaceae and the possible opportunistic pathogens. For example, the most dominant members of the bacteriotas in meat, such as Enterobacteriaceae (MØRETRØ \& LANGSRUD, 2017) and its commensal effect which contribute to competing with Salmonella Enteritidis for oxygen (LITVAK et al., 2019). This information is reinforced by GIROVA \& GOCHEV (2009) and ZWEIFEL et al. (2014) considering the contamination and competition of microorganism in meat.

Enterobacteriaceae are commonly associated with faecal contamination and environmental exposure, and included spoilage and pathogenic microorganisms. However, we did not detect any E. coli or Salmonella spp. in the sampled chilled meat.

Psychrotroph considerably increased with storage, exceeding $7 \log _{10} \mathrm{cfu} / \mathrm{cm}^{2}$ for both treatments (Table 5). This was not unexpected considering the natural microbiota of meat and storage conditions, which favour psychrotrophic growing. Microbiological, enzymatic, and chemical transformations that lead to meat deterioration can be considerably impeded by using adequate chilling and storage conditions, allowing for longer shelf life. By contrast, under anaerobic conditions, Lactobacillus sp. and other lactic acid bacteria, naturally present in meat, can contribute to the production of natural antimicrobial substances, bacteriocins, and inhibition of the growth of competing species (VAUGHAN et al., 1994; PRADO et al., 2000).

\section{CONCLUSION}

The SC treatment effectively reduced carcass weight loss, despite the short time of spraying evaluated in the current study. Therefore, SC can be used to reduce the economic losses associated with meat chilling. SC did not affect meat quality attributes, when considering the evaluated conditions, and did not enhance the bacterial spoilage of meat, even after a prolonged storage time. However, that was accomplished by a combination of good water quality, hygienic-sanitary processes, and storage conditions. These findings shed light on the bacterial population dynamics on refrigerated vacuum-packed meat. Hence, we believed that the meat microbioma is the best direction for future research, in the context of the meat microbiology, to evaluate methods or process to extend meat preservation.

Table 5 - Microbiological evaluation of vacuum-packed chuck tender beef cuts stored up to $60 \mathrm{~d}$ after the chilling treatments ( $\mathrm{n}=6$ for each chilling treatment/storage time).

\begin{tabular}{|c|c|c|c|c|c|c|c|c|}
\hline \multirow[t]{2}{*}{ Storage time (d) } & \multicolumn{2}{|c|}{$\begin{array}{l}\text { Enterobacteriaceae } \\
\qquad\left(\log _{10} \mathrm{cfu} / \mathrm{cm}^{2}\right)\end{array}$} & \multicolumn{2}{|c|}{$\begin{array}{c}\text { E. coli } \\
\left(\log _{10} \mathrm{cfu} / \mathrm{cm}^{2}\right)\end{array}$} & \multicolumn{2}{|c|}{$\begin{array}{l}\text { Psychrotrophs } \\
\left(\log _{10} \mathrm{cfu} / \mathrm{cm}^{2}\right)\end{array}$} & \multicolumn{2}{|c|}{$\begin{array}{l}\text { Salmonella spp. } \\
\left(\mathrm{cfu} / 300 \mathrm{~cm}^{2}\right)\end{array}$} \\
\hline & ----SC---- & -----CC----- & ----SC---- & ----CC---- & ------SC----- & -----CC---- & -----SC----- & -----CC----- \\
\hline 7 & 1.0 & 0.22 & $<1.0$ & $<1.0$ & $4.31^{\mathrm{a}}$ & $3.80^{\mathrm{a}}$ & 0 & 0 \\
\hline 30 & 2.73 & 0.92 & $<1.0$ & $<1.0$ & $7.41^{\mathrm{b}}$ & $7.10^{\mathrm{b}}$ & 0 & 0 \\
\hline 60 & 3.24 & 1.74 & $<1.0$ & $<1.0$ & $7.29^{b}$ & $7.18^{\mathrm{b}}$ & 0 & 0 \\
\hline
\end{tabular}

SC, spray chilling; CC, conventional air chilling. Data are shown as the means. Means in the same column denoted by different letters are significantly different. Nonparametric test - Kruskal-Wallis $(\mathrm{P}<0.05)$. 


\section{ACKNOWLEDGMENTS}

The authors would like to thank the Fundação de Amparo à Pesquisa do Estado de Goiás (FAPEG) for financia support, and JBS SA for help with animal and industry management, handling, and slaughtering. This study was financed in part by the Coordenação de Aperfeiçoamento de Pessoal de Nível Superior (CAPES), Brasil - Finance code 001.

\section{DECLARATION OF CONFLICT OF INTEREST}

The authors declare no conflict of interest. The founding sponsors had no role in the design of the study; in the collection, analyses, or interpretation of data; in the writing of the manuscript, and in the decision to publish the results.

\section{AUTHORS' CONTRIBUTIONS}

All authors contributed equally for the conception and writing of the manuscript. All authors critically revised the manuscript and approved of the final version.

\section{REFERENCES}

ALLEN, D. M. et al. Effects of spray chilling and carcass spacing on beef carcass cooler shrink and grade factors. Journal of Animal Science, v.64, p.165-170, 1987. Avaiable from: <https://academic.oup.com/jas/articleabstract/64/1/165/4654325>. Accessed: May. 5, 2021. doi: $10.2527 /$ jas $1987.641165 \mathrm{x}$.

AMSA - American Meat Science Association. Meat Color Measurements Guidelines. Champaign, Illinois, USA, 2012. Avaiable from: <https://meatscience.org/docs/default-source/ publications-resources/hot-topics/2012 12 meat clr guide. pdf?sfvrsn=d818b8b3_0>. Accessed: May. $\overline{7}, 2021$

APHA - American Public Health Association. Standard Methods for the examination of Water and Wastewater. Washington, USA: American Public Health Association, 2012.

AOAC 990.12-1994. Official Method Aerobic Plate Count in Foods, Dry Rehydrate Film (Petrifilm Aerobic Plate Count Plate Method). Official methods of analysis of AOAC International, 18th edition. Gaithersburg, MA, 2002

AOAC 998.08-2002. Escherichia coli Counts in Poultry, Meats, and Seafood, Dry Rehydratable Film Method (Petrifilm EC Plate Method). Official methods of analysis of AOAC International, 18th edition. Gaithersburg, MA, 2002.

BRASIL. Decreto No 9.013 Regulamenta a inspeção industrial e sanitária de produtos de origem animal. DE 29 DE MARÇO DE 2017, [S.1.], 2017. Available from: <http://www.planalto.gov. br/ccivil_03/_ato2015-2018/2017/decreto/D9013.htm>. Accessed: May. 7, 2021.

BROWN, T. et al. Spray chilling of lamb carcasses. Meat Science, v.34, p.311-325, 1993. Avaiable from: <https://www.sciencedirect com/science/article/pii/0309174093900802>. Accessed: May. 5, 2021. doi: 10.1016/0309-1740(93)90080-2.
CIE. International Commission on Illumination. Colorimetry: Official Recommendation of the International Commission on Illumination. Publication CIE No. (E-1.31). Paris, France: Bureau Central de la CIE, 1976

FERNÁNDEZ, A. M.; VIEIRA, C. Effect of chilling applied to suckling lamb carcasses on hygienic, physicochemical and sensory meat quality. Meat Science, v.92, p.569-574, 2012. Avaiable from: <https://www. sciencedirect.com/science/article/pii/S0309174012002021>. Accessed: May. 5, 2021. doi: 10.1016/j.meatsci.2012.05.029.

FRANCO, D. et al. Effect of finishing and aging time on quality attributes of loin from the meat of Holstein-Fresian cull cows Meat Science, v.83, p.484-491, 2009. Avaiable from: <https:// www.sciencedirect.com/science/article/pii/S0309174009001892>. Accessed: May. 5, 2021. doi: 10.1016/j.meatsci.2009.06.030.

GIGIEL, A. et al. Alternative methods of pig chilling. Meat Science, v.26, p.67-83, 1989. Avaiable from: <https://www. sciencedirect.com/science/article/pii/0309174089900570>. Accessed: May. 5, 2021. doi: 10.1016/0309-1740(89)90057-0.

GIROVA, T. D.; GOCHEV, V. K. (2009). Detection and enumeration of spoilage and pathogenic microorganisms in refrigeratory stored meat products. Biotechnology \& Biotechnological Equipment, v.23:sup1, p.896-899, 2009. Avaiable from: <https://www.tandfonline.com/doi/pdf/10.10 80/13102818.2009.10818567>. Accessed: May. 7, 2021. doi: $10.1080 / 13102818.2009 .10818567$.

GREER, G. G. et al. Effect of spray-chilling on the quality, bacteriology and case life of aged carcasses and vacuum packaged beef. Canadian Institute of Food Science and Technology Journal, v.23, p.82-86, 1990. Avaiable from: <https://www. sciencedirect.com/science/article/pii/S0315546390702064>. Accessed: May. 7, 2021. doi: 10.1016/S0315-5463(90)70206-4.

GRERR, G. G.; JONES, S. D. M. Quality and bacteriological consequences of beef carcass spray-chilling: Effects of spray duration and boxed beef storage temperature. Meat Science, v.45, p.61-73, 1997. Avaiable from: <https://www.sciencedirect.com/ science/article/pii/S0309174096000733>. Accessed: May. 5, 2021. doi: 10.1016/S0309-1740(96)00073-3

ISO - International Organization for Standardization. 6222:1999 Water quality-Enumeration of culturable microorganismsColony count by inoculation in a nutrient agar culture medium. 2th edition. Switzerland. 4p, 1999.

ISO - International Organization for Standardization. 6579:2004/ COR1:2004 Microbiology of food and animal feeding stuffsHorizontal methods for the detection of Salmonella spp.Technical Corrigendum 1. Switzerland. 1p, 2004.

ISO - International Organization for Standardization. 215282:2004 Microbiology of food and animal feeding stuffsHorizontal methods for the detection and enumeration of Enterobacteriaceae-Part 2: Colony-count method. 1st edition. Switzerland. 10p, 2004

$\mathrm{JACOB}$, R. et al. Rapid tenderisation of lamb M. longissimus with very fast chilling depends on rapidly achieving sub-zero temperatures. Meat Science, v.92, p.16-23, 2012. Avaiable from: $\quad<$ https://www.sciencedirect.com/science/article/pii/ S030917401200109X>. Accessed: May. 5, 2021. doi: 10.1016/j. meatsci.2012.03.015 
JACOB, R. H.; THOMSON, K. L. The importance of chill rate when characterising colour change of lamb meat during retail display. Meat Science, v.90, p.478-484, 2012. Avaiable from: <https:// www.sciencedirect.com/science/article/pii/S0309174011003160>. Accessed: May. 5, 2021. doi:10.1016/j.meatsci.2011.09.011.

JANZ, J.A. M.; AALHUS, J. L. Meat quality, bacteriology and retail case life of bison Longissimus lumborum following spray chilling. Journal of Muscle Foods, v.17, p.330-342, 2006. Avaiable from: <https:// onlinelibrary.wiley.com/doi/full/10.1111/j.1745-4573.2006.00053.x>. Accessed: May. 7, 2021. doi: 10.1111/j.1745-4573.2006.00053.x.

JONES, S. D. M.; ROBERTSON, W. M. The effects of spraychilling carcasses on shrinkage and quality of beef. Meat Science, v.24, p.177-188, 1988. Avaiable from: <https://www.sciencedirect. com/science/article/pii/0309174088900769>. Accessed: May. 5, 2021. doi: 10.1016/0309-1740(88)90076-9.

LEE, M. S. et al. Influence of vacuum-aging period on bloom development of the beef gluteus medius from top sirloin butts. Meat Science, v.80, p.592-598, 2008. Avaiable from: <https:// www.sciencedirect.com/science/article/pii/S0309174008000466>. Accessed: May. 5, 2021. doi: 10.1016/j.meatsci.2008.02.006

LINDAHL, G. Colour stability of steaks from large beef cuts aged under vacuum or high oxygen modified atmosphere. Meat Science, v.87, p.428-435, 2011. Avaiable from: $<$ https://www.sciencedirect com/science/article/pii/S0309174010004286>. Accessed: May. 5, 2021. doi: 10.1016/j.meatsci.2010.10.023.

LITVAK, Y. et al. Commensal Enterobacteriaceae Protect against Salmonella Colonization through Oxygen Competition. Cell Host \& Microbe, v.25 (1), p.128-139, 2019. Avaiable from: <https:// pubmed.ncbi.nlm.nih.gov/30629913/>. Accessed: May. 7, 2021. doi: 10.1016/j.chom.2018.12.003.

MACDOUGALL, D. B. Changes in the colour and opacity of meat Food Chemistry, v.9, p.75-88, 1982. Avaiable from: <https:// www.sciencedirect.com/science/article/pii/030881468290070X > Accessed: May. 7, 2021. doi: 10.1016/0308-8146(82)90070-X.

MANCINI, R. A.; RAMANATHAN, R. Effects of postmortem storage time on color and mitochondria in beef. Meat Science, v.98, p.65-70, 2014. Avaiable from: <https://www.sciencedirect. com/science/article/pii/S0309174014001119>. Accessed: May. 6, 2021. doi: 10.1016/j.meatsci.2014.04.007.

MESQUITA, A. J. et al. The effects of spray-chilling associated to conventional chilling on mass loss, bacteriological and physicochemical quality of beef carcass. Ciência Animal Brasileira, v.4, p.145-153, 2003. Avaiable from: <https://www.revistas.ufg.br/ index.php/vet/article/view/304>. Accessed: May. 7, 2021.

MOMBEINI, E. G. et al. Effects of high voltage electrical stimulation on the rate of $\mathrm{pH}$ decline, meat quality and color stability in chilled beef carcasses. Asian Pacific Journal of Tropical Biomedicine, v.3(9), p.716-719, 2013. Avaiable from: <https:// www.sciencedirect.com/science/article/pii/S2221169113601446>. Accessed: May. 6, 2021. doi: 10.1016/S2221-1691(13)60144-6.

MØRETRØ, T.; LANGSRUD, S. Residential bacteria on surfaces in the Food Industry and Their Implications for Food Safety and Quality. Comprehensive Reviews in Food Science and Food Safety, v.16, p.1022-1041, 2017. Avaiable from: <https:// onlinelibrary.wiley.com/doi/full/10.1111/1541-4337.12283>. Accessed: May. 6, 2021. doi: 10.1111/1541-4337.12283.
MUCHENJE, V. et al. Relationship between pre-slaughter stress responsiveness and beef quality in three cattle breeds. Meat Science, v.81, p.653-657, 2009. Avaiable from: <https://www. sciencedirect.com/science/article/pii/S0309174008003677>. Accessed: May. 6, 2021. doi: 10.1016/j.meatsci.2008.11.004.

PRADO, C. S.; DE FELÍCIO, P. E. Effects of chilling rate and spray-chilling on weigh loss and tenderness in beef strip loin steaks. Meat Science, v.86, p.430-435, 2010. Avaiable from: $<$ https:// www.sciencedirect.com/science/article/pii/S0309174010002147>. Accessed: May. 6, 2021. doi: 10.1016/j.meatsci.2010.05.029.

PRADO, C. S. et al. (2000). Atividade antimicrobiana de bactérias lácticas de embutidos curados frente a Listeria monocytogenes [Antimicrobial activity of lactic acid bacteria isolated from Brazilian dry fermented sausages against Listeria monocytogenes]. Arquivo Brasileiro de Medicina Veterinária e Zootecnia, v.52, p.417-423, 2000. Avaiable from: <https://www.scielo.br/scielo. php?pid $=$ S010209352000000400022\%094\&script=sci_arttext $>$. Accessed: May. 6, 2021. doi: 10.1590/S0102-09352000000400022.

ROSENVOLD, K.; WIKLUND, E. Retail colour display life of chilled lamb as affected by processing conditions and storage temperature. Meat Science, v.88, p.354-360, 2011. Avaiable from: <https:// www.sciencedirect.com/science/article/pii/S0309174011000192>. Accessed: May. 6, 2011. doi: 10.1016/j.meatsci.2011.01.006.

STRYDOM, P. E.; BUYS E. M. The effects of spray-chilling on carcass mass loss and surface associated bacteriology. Meat Science, v.39, p.265-276, 1995. Avaiable from: <https://www. sciencedirect.com/science/article/pii/0309174094P1827I>. Accessed: May. 6, 2021. doi: 10.1016/0309-1740(94)P1827-I.

TROY, D. J. \& KERRY, J. P. Consumer perception and the role of science in the meat industry. Meat Science, v.86, p.214-226, 2010. Avaiable from: <https:/www.sciencedirect.com/science/article/ pii/S0309174010001865>. Accessed: May. 6, 2021. doi: 10.1016/j. meatsci.2010.05.009.

USDA - United States Department of Agriculture. Institutional Meat Purchase Specifications for fresh beef products: Fresh beef series 100. 2014. Agricultural Marketing Service, Washington, DC. Avaiable from: <https://www.ams.usda.gov/sites/default/files/media/ IMPS_100_Fresh_Beef\%5B1\%5D.pdf >. Accessed: Mar. 9, 2018.

VAUGHAN,E.E. etal.Isolation fromfoodspurces, oflacticacidbacteria that produced antimicrobials. Journal of Applied Microbiology, v.76, p.118-123, 1994. Avaiable from: <https://sfamjournals.onlinelibrary. wiley.com/doi/abs/10.1111/j.1365-2672.1994.tb01606.x>. Accessed: May. 6, 2021. doi: 10.1111/j.1365-2672.1994.tb01606.x.

WHEELER, T. L. et al. Shear Force procedures for meat tenderness measurement. 1998. Avaiable from: <http://www.meats.marc.usda. gov/MRU_WWW/Protocol/WBS.pdf>. Accessed: Mar. 18, 2002.

WIKLUND, E. et al. Spray chilling of deer carcasses - Effects on carcass weight, meat moisture content, purge and microbiological quality. Meat Science, v.86,p.926-930,2010. Avaiable from: $<$ https:// www.sciencedirect.com/science/article/pii/S0309174010002974>. Accessed: May. 5, 2021. doi: 10.1016/j.meatsci.2010.07.018.

ZWEIFEL, C. et al. Microbiological contamination of cattle carcasses at different stages of slaughter in two abattoirs. Meat Science, v.98, p.198-202, 2014. Avaiable from: <https://www. sciencedirect.com/science/article/pii/S0309174014001600>. Accessed: May. 6, 2021. doi: 10.1016/j.meatsci.2014.05.029. 